\title{
Michał Kłosiński*
}

University of Silesia in Katowice

\section{BLACK MONEY AS THE MATTER OF NEO-LIBERAL UTOPIA - READING [C] THE MONEY OF SOUL AND POSSIBILITY CONTROL ${ }^{1}$}

\begin{abstract}
The paper: Black money as the matter of neo-liberal utopia, reading [C] The Money of Soul and Possibility Control is dedicated to the problem of the neoliberal utopia of debt. The author analyses the anime series directed by Kenji Nakamura for motifs and representations linked with economics: black money, debt, the Midas bank. The article focuses on analysis and interpretation of the relation between black money and production of utopian hyperreality and on the problem of debt, competition and corruption of the general equivalent as the main pillars of both a presentation and critique of the neoliberal utopia. In his interpretation the author relates to classical researchers of utopia (Fredric Jameson, Lyman Tower Sargen, Geoffrey Hodgson) and to the contemporary critics of neoliberalism (Franco "Bifo" Berardi, Maurizzio Lazzarato, Pierre Bourdieu, and Slavoy Žižek).
\end{abstract}

Keywords: black money, neoliberalism, utopia, debt, anime, Nakamura

\section{INTRODUCTION}

The main hypothesis of this paper is that Kenji Nakamura's anime [C] The Money of Soul and Possibility Control is a contemporary representation of a neoliberal utopia (Bourdieu 1998) of debt, which would be one of the possible iterations of what Geoffrey Hodgson calls in his Economics and Utopia the "utopia of market individualism" (Hodgson 1999: 64). Unfortunately, neither Bourdieu nor Hodgson give much insight into the problem of debt in their works, and debt is central to my understanding of the neoliberal utopia. In the first part of my article, I work on several problems linked with the question of desire (Jameson 2005: 2-5), social dreaming (Sargent 1994: 8-10) and the neoliberal reconstitution of the individual into an entrepreneur (Hodgson 1999: 76). The main focus here is on how neoliberalism utilizes, at its core, a specific utopian dimension (Dean and Fisher 2014: 34-35). The second part of the paper focuses on the role and place of debt in the neoliberal utopia presented in [C] The Money of Soul. Here I am relating to the innovative line of Italian thinkers who have worked on the question of turning one's future into collateral (Lazzarato

* Corresponding author: Michał Kłosiński, ul. Morawa 91D/42, 40-353 Katowice; e-mail: michal.klosinski@us.edu.pl.

1 The project was founded by the National Science Centre in Poland (No. DEC-2012/05/D/HS2/03589). 
2012; Berardi 2012). The third part focuses on linking the problem of debt with the notion of hyperreality (Baudrillard 1983) to show that the neoliberal utopia of debt capitalizes on the crisis of representation and endangers the real in the name of sustaining the present world by sacrificing its future alternatives. The main hypothesis here is that the neoliberal utopia of debt is anti-utopian at its core, as it nullifies the possible alternatives that might endanger its existence.

The anime I am going to discuss is a production directed by Kenji Nakamura, who is well known for works such as Mononoke and Gatchaman Crowds. [C] The Money of Soul and Possibility Control is unique animation focusing solely on the problems of economics in the smallest details. To begin with, the story takes place in Japan shortly after the intervention of a sovereign wealth fund to prevent an economic crisis. The protagonist - Kimimaro Yoga - is a student of economics living in poverty after his father's suicide (caused by the bankruptcy of his business), and his only dream is to get a safe job in the public sector. The story begins when he receives an invitation to the utopian-like "Financial District", located outside of reality, a place constructed as mirror image of the countries' economy and governed by a big clock counting virtual credit. Furthermore, the only way to access the Financial District and utilize profits gained in it is by using a diabolical black credit card. This in turn can only be done by making a deal with a shady character named Masakaki, who is the Financial District's main supervisor and works for the commercial division of its governing institution, the Midas Bank. By signing a contract with Masakaki, one trades his future which is then transformed into "assets" and only then is he granted access to the Financial District and can use his money of the soul freely in and outside of it. If that was not enough, the main currency of the Financial District - black money - can only be earned by taking it from other participants through money battles. Thus only by taking the monetized future of others can one hope to change the economy and the shape of the "real" world. It is worth noting that the names of participants (entrepreneurs), the virtual world (Financial District), and the main bank (Midas) all work as a part of the symbolic sphere related to economics. This is also represented in the opening to the anime series, in which the camera literally "enters" different banknotes as if it was going into a political and economic history of the states that issue them.

The main point of my paper is to analyze and interpret this specific representation or representations of a neo-liberal economy from the perspective of utopia. I will focus on the specifics of the hyperreality of both the Financial District and the world influenced by the black money. I will also try depict how the vision of debt in [C] The Money of Soul can be understood as a radical critique of the contemporaneity, the mechanisms of creating an indebted man and constructing a world on the basis of simulacra. My aim is also to show the relationship between the neoliberal debt ideology and hyperreality of simulation which work together as a mechanism robbing a human being of its future. Last but not least, I will try to show how this particular anime presents neo-liberal utopia, and how it strips this vision to the core of what it really is. The ultimate goal of this paper is thus the deconstruction of the neoliberal utopia depicted in [C] The Money of Soul. 


\section{THE CREDIT CARD AS A KEY TO THE NEO-LIBERAL UTOPIA}

Before one enters the Financial District he has to make a deal with the main banker Masakaki, who - with his grim smile and shady way of appearing before each "entrepreneur" - reminds us more of the devil himself from Goethe's tragedy about Doctor Faust, than of a parody of Japanese economist Masakaki Shirakawa ${ }^{2}$, who wrote extensively on the problem of money and monetary policy. Masakaki truly resembles the figure of Goethe's Mephistopheles, dressed in colorful clothes that make him look like a joker or magician - or as Goethe writes, "a goliard" (Conf:: Goethe 2014: 35), or traveling scholar. Masakaki also holds a cane with a small representation of King Midas's head; Mephisto holds a sword. His strong resemblance to Mephistopheles can also be seen in the fact that he is only one of many similar entities, each of which governs a specific financial district in a different country. The same feature is presented in Faust:

FAUST. You call yourself a part, yet stand before me whole?

MEPHISTOPHELES. I only speak the sober truth.

You mortals, microcosmic fools,

may like to think of yourselves as complete,

but I'm a part of the Part that first was all.

(Goethe 2014: 36)

Both Mephisto and Masakaki appear as independent parts of a more complex entity, and they also tend to visit their clients or victims at night and at home. Thus the futuristic and neo-liberal devil retains the modus operandi of his romantic cousin. It is also imperative to see the offer which the devil makes in both cases. In Faust, Mephisto offers his service to the professor under the famous condition:

If I should ever say to any moment:
Tarry, remain! - you are so fair!
then you may lay your fetters on me,
then I will gladly be destroyed!

(Goethe 2014: 44)

If this condition is met than Faust will be the one who serves Mephisto in the afterlife. On the other hand, Masakaki from [C] Money of Soul presents a different set of rules and regulations in his pact with the human being. In the extra video uploaded to the series website he describes the nature of the deal to get the black credit card:

There is only one rule that the people that frequent the Financial District, called Entrepreneurs, must obey: to participate once a week on the Deals that we promote. That is all. If you win, you profit; if you lose, you take a loss. It is extremely simple. We do not mind if you use the money you earned in the real world. In exchange, if you forgive me for saying... Your future will be taken as collateral. Huh? What do I mean by future, you ask? It could be your children or your dreams for the future. For a certain college student and Entre, it is the daughter or granddaughter that

2 This is a lead pointed by the [C] Money of Soul wikia: http://soulcontrol.wikia.com/wiki/Masakaki [09.03.2015]. 
should be born someday; For a certain powerful Entre, it's the little sister that never wakes from her slumber; It varies from person to person. Have I managed to clarify things a little bit? Until now, there have been people that attempted to use the fortune they earned to support reality; and there were others that attempted to recover the future lost because of that. We don't mind if you act to your heart's content. We are quite... lenient. ${ }^{3}$

In the case of Mephisto and Faust it was the soul in the afterlife that was the wager of the diabolical deal. But in the neoliberal world there is not a hint of any afterlife, heaven or hell, there are only two rules: 1 . You must compete with others for money; 2. You must offer your future in exchange for the entry to the district and agree to the fact that if you go bankrupt - your future will evaporate as your asset. Let us look closer at these conditions, as their difference marks two distinct narratives driven by two different utopian (or dystopian) impulses (Conf.: McManus 2003: 7). As Fredric Jameson points out: "Bloch posits a Utopian impulse governing everything future-oriented in life and culture;" (Jameson 2005: 2). The main difference between the two analyzed diabolical pacts is in defining the future: going on a journey with Mephisto, Faustus takes a wager for his soul, but at the same time he is not yet lost; he is granted all the powers to experience an alternative to his current mundane life without any prior sacrifice. The situation is quite different with Masakaki, as his deal is exactly what goes against the very formula of utopian impulse. By saying that "your future will be taken as collateral" he transforms the utopian impulse into a hostage of economics: your future now has been transformed into your asset and is completely dependent on you making and losing money, on weekly deals you must participate in. Obtaining a black credit card and thus entering the utopia of the Financial District is at the same time - paradoxically underpinned by a law that makes one renounce his utopian impulse in favor of its economized equivalent: assets and black money. Also, the power to change reality with the use of the black money, the power to create utopia and to realize the utopian impulse in the real world, is transformed into something absolutely dependent on competition: if you want your utopia to last, you must earn more money, hurt other people, take away their future to build yours. This is the effect of what Goeffrey Hodgson in his Economics of Utopia calls a socio-economic reconstitution of an individual (Hodgson 1999: 76-78) and which is strictly linked with the market understood always as a specific social space (Hodgson 1999: 94-97). Hodgson thus helps us to understand that [C] The Money of Soul tries to represent the mechanisms of a specific neoliberal desire-driven market of the Financial District.

But is the Financial District a neoliberal utopia? Let us see whether the very definition of neoliberalism as given by Pierre Bourdieu will hint at what to look for when thinking about its utopianism:

Neoliberalism tends on the whole to favor severing the economy from social realities and thereby constructing, in reality, an economic system conforming to its description in pure theory, that is a sort of logical machine that presents itself as a chain of constraints regulating economic agents. (Bourdieu 1998)

3 This English transcription was uploaded to the series wikia along the subbed video: http://soulcontrol.wikia. com/wiki/Masakaki [09.03.2015]. 
It is crucial to answer the question about the status of the fictional town of Kabuto, the alternate name of the Financial District. The first fact about this non-place is that it is an enclave, with a limited number of people who can enter its premises. Moreover, at the beginning of the second episode, when Masakaki takes Kimamro Yoga to the district for the first time, it is presented in one take as a place where people loiter frivolously, spend their free time, and feel relaxed. But this one scene soon changes into a vision of a stock market and a battleground, where entrepreneurs hurt each other to gain money. Kabuto town is thus an ambivalent place where people come mainly to participate in deals, or watch others battling, but not a typical place to live in - there is probably no one who actually lives there. At the same time, a person working as an information broker in the district tells Kimimaro one of the truths about this world: "Living more here than in the real world. That means living longer." (Nakamura 2011: ep 3). Once someone gains access to the district, he has to balance his time between reality and time spent doing business. As such, it is an ideal and utopian market space that Bourdieu defines as the neoliberal utopia: "Thus we see how the neoliberal utopia tends to embody itself in the reality of a kind of infernal machine, whose necessity imposes itself even upon the rulers." (Bourdieu 1998). Moreover, we must also take into consideration the fact that one does not enter the Financial District for the sake of living in it, but to change an unbearable reality. The district functions as virtual means to a real end. Kimimaro Yoga decides to enter the district after his conversation with Masakaki:

Masakaki: Do you not desire money?

Yoga: As if I needed such strange money.

Masakaki.: You could go out drinking. You wouldn't have to work two jobs at once. You could have a secure life without becoming a public employee. (Nakamura 2011: ep 3.)

And a bit further, after Yoga decides to withdraw the black money from an ATM, Masakaki tells him one of the most important things about the utopia of Financial District:

Masakaki: So, you do need money. After all its money, right? Wouldn't you like to try and make some more? If it goes well you could get anything. Her heart for example...

Kimimaro: Hanabi has a boyfriend!

Masakaki: It seems her boyfriend is some rich kid. The thing that sets him apart from you, is in all likelihood, money. (Nakamura 2011: ep 3.)

The Financial District offers an alternative to reality with the use of black money. In fact, the black money which symbolizes the district is utopian in the very way it is presented: as an alternative to the real money which is the result of real work. What Masakaki tells Kimimaro is that he will no longer have to work to earn money, and that he will receive enough black currency to fulfill his dreams, even get the girl he loves. The utopian perspective is thus hidden not in the existence of a non-place, but in the existence of the simulacrum of money detached from real work, labor, and social relations.

I am relating here to two different definitions of utopia and utopianism. The first would be the one described by Lyman Tower Sargent in his article about different utopias, where he defines utopianism as social dreaming (Sargent 1994: 9). The anime presents a vision of a neoliberal devil offering black money as a means of fulfilling various social dreams. What 
is utopian is the dream each and every one has, a dream which cannot be fulfilled by means taken from reality, by hard and exhausting labor. What the neoliberal devil offers is the utopia of a never-ending supply of currency. Masakaki says:

This is the invitation to the Financial District. Those who take it, without exception, gain the right to enter that area. You are free to withdraw money from any ATM. But we take your future as the collateral. (Nakamura 2011: ep 3)

The Financial District is thus a vision obscuring the real utopian dream - to be able to withdraw black money from any ATM, to always have money. This is what I will call the neoliberal utopian dreaming presented in [C] Money of Soul, the dreaming which neoliberalism capitalizes on, which is the subject of all its mechanisms. The social dreaming of neoliberalism amounts to instantaneous accessibility to unlimited amount of money. This is also the point where I believe it is imperative to supplement Sargent's definition with Jameson's reflection taken from Bloch on the utopia as an alternative, as a desire - the utopian impulse (Jameson 2005: 2-5). The Financial District is an enclave for those who desired an alternative, for those who rejected the money earned by real labor and turned to black money - or the collateral future being at stake in every duel-deal. The neoliberal utopia is thus built on the premise that the future has to be sacrificed in order to fulfill one's desires and that taking it from other people is justified for the sake of survival both in the real world and in the virtual one. Almost every character depicted in [C] Money of Soul believes that the system they live in is inevitable, but at the same time they believe that it is the best of all possible systems and an alternative to the harsh reality of a country in crisis. This thesis about neoliberalism is discussed by Pierre Bourdieu in his article Utopia of endless exploitation (conf. Bourdieu 1998) and by Jodi Dean and Mark Fisher in relation to Slavoj Žižek's thesis about capitalist utopia. These researchers look for utopia in two different iterations of capitalism: capitalist realism (which resembles the social realism of the $20^{\text {th }}$ century) and neoliberalism, which goes beyond it:

Jodi Dean: [...] Žižek says that there is a utopian core in neoliberal capitalism - the idea that this is the best system. Would you say that this is the other side of your more dystopian capitalist realism, perhaps the capitalist side or the side of the ruling class?

Mark Fisher: This is complicated - because on the face of it capitalist realism can be characterized by its repudiation of any utopianism. That repudiation is what the "realism" consists of. What we saw on the parliamentary left was an abandonment of anything that could be construed as utopian, a rhetorical performance of pragmatic adaptation to a narrowly conceived model of the possible. But if there is an ineradicable utopian core to neoliberalism, then this reveals the differences between capitalist realism and neoliberalism. Neoliberalism has succeeded because it was capable of subordinating the left to capitalist realism, but the two tendencies are not identical. Where capitalist realism is anti-utopian, neoliberalism does have a utopian dimension. (Dean and Fisher 2014: 34-35)

The utopian dimension of neoliberalism can be seen in [C] Money of Soul in the promise of unbelievable gains attached to the black credit card. One of the characters in the anime utilizes the black money to counter the effects of Japan's recession and pumps it into the country's economy. This is done under the premise of securing the future, but one might argue 
that it only serves to sustain the status-quo created by neoliberal capitalism: the gestures of good will from the wealthy are just more filthy propaganda that neoliberalism procures to justify its greed and to present itself in a good light (Conf. Žižek 2009: 98-99). On the other hand, investing black money into the country's economy means that with the investor dying or losing his future, the country will plunge into chaos as the black money used to stabilize it will disappear.

To sum up, the vision of neoliberalism presented in [C] Money of Soul is based on two things: 1. unlimited consumption of black money as the currency of desire, and 2. the repudiation of work in favor of competition. The whole Financial District is thus built as a mirror image of the classical neoliberal city (or the city in the city, the true residence of financial capitalism) where people consume and compete, invest their own futures, and take away the futures of others.

\section{FUTURE AS COLLATERAL - DEBT-TOPIA}

What does it mean to turn someone's future into collateral? In [C] The Money of Soul this is depicted as a constant process of negotiating the size of one's black money assets and things which represent them in reality. For example, when Kimimaro Yoga defeats one of his opponents, a teacher he knows from the real world, the teacher goes bankrupt, is evicted from the Financial District, loses his children as if they were never born, and his wife divorces him. This all happens the instant he returns to reality, in fact he and all "entrepreneurs" always return to a different reality after each deal: on one occasion Kimimaro returns to see Japan transformed from a $20^{\text {th }}$-century commercial paradise into a $19^{\text {th }}$-century industrial hell. This process of negotiating between the size of one's wallet, one's assets and one's reality is best described in a conversation between Kimimaro and Kō Sennoza:

Sennoza: Have a look at this. Children from the countries I'm donating vaccines to drew me these pictures. Because they have nothing else to give in return. The theme in their pictures is always the same. Can you tell what it is?

Yoga: Aren't they always different? Cities and people...

Sennoza: It's all the future. What their poor countries will turn into. The people they want to become. Yoga: I see.

Sennoza: I have only lost a deal once. It wasn't that significant of a loss, but loss is a loss. Then when I returned I realized... A few of the pictures I hung here were replaced.

Yoga: That means...

Sennoza: They disappeared. Along with the futures depicted in them. (Nakamura 2011: ep 6)

The process of turning one's future into collateral quite clearly depicts the very essence of what Maurizio Lazzarato and Franco "Bifo" Berardi call the process of creating an indebted man (Conf. Lazzarato 2012; Berardi 2012). To enter the Financial District one receives the black credit card, a tool without which it is impossible to utilize one's assets when making deals, to pay for things in the district, or to withdraw black money from ATMs. The credit card in itself is also a means of looking at one's assets, which differ from person to person, as 
the form they take represents the future of their holders. Metaphorically the black credit card is both a window and a cage, a safe or a crypt where one has buried his future. Moreover, the card offers everyone an illusion of holding their future in their hands, an illusion of being in control. In The making of an indebted man Lazzarato writes:

We carry within us the creditor-debtor relation - in our pockets and wallets, encoded in the magnetic strip on our credit cards. Indeed, this little strip of plastic hides two seemingly harmless operations: the automatic institution of the credit relation, which thereby establishes permanent debt. The credit card is the simplest way to transform its owner into a permanent debtor, an "indebted man" for life. (Lazzarato 2012: 20)

In [C] The Money of Soul this eternal creditor-debtor relationship is established as a part of the diabolical pact to enter the Financial District. There is only one way to escape the district and that is to go bankrupt, to lose the future - and with it the very temporal dimension that life's vector is set on: to escape neoliberalism one has to die (or become a homo sacer). Furthermore, the very logic of transforming one into an "entrepreneur" is already a logic of making him an indebted man. Lazzarato points to the fact that entrepreneurship is already a process of turning an individual into a small business:

To make an enterprise of oneself (Foucault) - that means taking responsibility for poverty, unemployment, precariousness, welfare benefits, low wages, reduced pensions, etc., as if these were the individual's "resources" and "investments" to manage as capital, as "his" capital. As we can very clearly see, the concepts of entrepreneur of the self and human capital must be interpreted by way of the creditor-debtor relationship. (Lazzarato 2012: 51)

By becoming an entrepreneur Kimimaro Yoga not only transforms his future into collateral, he transforms himself into his own capital, and this is true for all inhabitants of the Financial District - that is why they no longer truly bleed when dueling for profit, they bleed black money, as it has become their source of life, the only real flow sustaining their system. The money bleeding also sheds some light on the very essence of being an entrepreneur - vampirism. In his book on the Poetics of money Johen Hörisch has pointed to the fact that Dracula, the most well-known vampire, bleeds money when wounded (Hörisch 2000: 278-286). That is why the deals the entrepreneurs in [C] The Money of Soul are making are based on bleeding opponents dry of blood-money and gaining what the other party has lost. Neoliberal entrepreneurs are thus money-suckers bound to this fate by the debt - black money flowing in their veins.

Taking all this into consideration, the neoliberal utopia presented in [C] The Money of Soul should be called a debt-topia, as opposed to the original Utopia of Tomas More, which by repudiation of money and private property sought to eradicate economic inequality. The debt-topia would then be a very specific iteration of an anti-utopia built on the ambivalent nature of debt: by taking your future as a collateral it gives one the means to fulfill one's social dreams, desires and utopian impulses. This paradox is also inscribed in the essence of what the debtor has become: by turning himself into an enterprise he is no longer of flesh and blood; he has become his own capital, living only to produce and sustain himself with black money. Moreover, as the black money is disjoined from labor, the only possibility to obtain it is to take it from someone else - to rob him of his future. In the debt-topia presented in 
[C] The Money of Soul nobody has to work, nobody is poor, but nobody can escape it except for going bankrupt; there is no inequality: everyone is equally indebted to the Midas Bank, and there are no crimes as violence is constantly occurring during the deals to earn black money.

\section{BLACK MONEY AS SIMULACRUM; COLLAPSE OF DEBT-TOPIAN HYPERREALITY}

The only currency of the debt-topia is the mystical and diabolical black-money. These banknotes are only visible in their true black form to the entrepreneurs, and are completely indistinguishable to the people in the world outside of the Financial District. One could say that it is simple and well known counterfeit money, and would be accurate in saying that. The problem arises when there is no real way of discerning it or proving that it is false. This is when the notion of simulacrum seems to perfectly describe the problem we are facing. According to Baudrillard, the simulacrum nullifies the division between the true and the false, real and counterfeit, as it is opposed to the referentiality of both the sign and the image. Its principle is not to represent anything but itself, and thus it is dangerous to the reality from which it expels any reference. Baudrillard writes:

So it is with simulation, insofar as it is opposed to representation. The latter starts from the principle that the sign and the real are equivalent (even if this equivalence is utopian, it is a fundamental axiom). Conversely, simulation starts from the utopia of this principle of equivalence, from the radical negation of the sign as value, from the sign as reversion and death sentence of every reference. Whereas representation tries to absorb simulation by interpreting it as false representation, simulation envelops the whole edifice of representation as itself a simulacrum. (Baudrillard 1983: 11)

Baudrillard's thesis is simple: representation becomes simulation. But he also says another thing very important to our reading of [C] The Money of Soul and the metaphor of black money, that the principle of equivalence between the sign and the real is utopian and that simulation capitalizes itself on the very utopia of representation. On this premise and in relation to Baudrillard and Jean Joseph Goux, John Chung claims that money in neoliberalism and contemporary society has become a simulacrum because its referentiality (the famous gold standard) has ceased to exist, he writes:

Throughout most of history, money was either a thing of value in and of itself, or it was a symbol of the thing of value. Today, however, money is neither. No longer is paper money a symbol; it is the money, by itself. (Chung 2009: 120)

Taking this into consideration the problem of black money seems even more intriguing. If the "real" money is already a simulacrum, then the black money would be a simulacrum of a simulacrum. To complicate things a bit further, we must finally take into consideration what the title of [C] The Money of Soul suggests, that the currency subjected to our analysis is either an effect of selling one's soul to the devil (described in the first part of this paper), or that it is literally a general equivalent for the human soul, soul understood as the locus of infinite possibilities or - the locus of the utopian impulse. One thing is certain, the anime 
distinguishes the money of soul from other currencies (Japanese Yen, US Dollar). Thus, if every currency can be represented by the black money and at the same time the black money stays itself, it is the very and absolute general equivalent. Furthermore, this equivalence is established in order to distinguish the real from the fake, good from bad, but only to those who can see it - the entrepreneurs, meaning that the duality of time and space which divides the Financial District from the world which it represents is already a simulacrum working to destroy the very foundation it was built on. The Financial District and black money are simulacra installed at the heart of each country's economy, and it is precisely because they are simulacra that they are able to influence that economy: through the redoubling they erode it and turn it into hyperreality.

This vision presented in [C] The Money of Soul is a very interesting way of seeing our quotidian life through a lens of neoliberalism (with its utopia and mechanisms of control), neoliberalism deconstructed through subtle play with its utopian logic of general equivalence. The black money or the money of soul represents the future of the one who enters a creditordebtor relationship, the one who dares to dream of an alternative within the system already under the influence and control of its mirror - the Financial District. This is the perfect allegory of hyperreality - to change the world one has to enter its mirror ${ }^{4}$. And mirrors play a significant role in [C] The Money of Soul: in the Financial District they show the shape of one's assets - as if they mirrored the soul's capitalized future. For example Kimimaro Yoga's asset looks like his granddaughter.

The Japanese anime tells us even more about the nature of the neoliberal hyperreality. This becomes clear in a conversation between Kimimaro Yoga and his mentor and rival Mikuni Souichiro:

Mikuni Souichiro: It was scary that the Midas Money is mixed with the money we use every day. [...] The Midas Money is obviously bad. But then I realized that both the Financial District and Midas Money are shockingly real. We can't overturn the Financial District without turning reality upside-down. We can't destroy the system that transfers Midas Money or stop its flow. Then we don't have a chance but to coexist. [...] We buy Japanese national bonds with Midas Money to stop the country's collapse. We don't have a chance unless we control the balance so that both worlds profit. Kimimaro Yoga: Though you know it's bad?

Mikuni Souichiro: Reality is already taking Midas Money for granted. It would collapse if we stopped the flow. A lot of people would meet misfortune. (Nakamura 2011: ep 5)

It would seem that the creditor-debtor relationship which the Financial District imposes on individuals has become the principle of the existence of the world in the moment when the black money started flowing into it. Mikuni Souichiro, the most influential man in the Financial District, who has decided to fix the Japanese economy using black money, confirms the fact that it would be impossible to cut off the real world from the neoliberal debt-topia, as it would mean the collapse of "reality". It is quite interesting as the flow of black money and existence of hyperreality becomes the necessary evil in order to save reality and to avoid

\footnotetext{
4 Mirrors as tools for doubling one's image are a well-known Baudrillardean problem, for further insight into
} his understanding of the problem of the double (Conf. Smith 2010: 54-57). 
misfortune. But to be honest, what Mikuni proposes is for "reality" to be balanced against "hyperreality", for the world that has a future to be balanced against a world built on future turned into collateral. And we Europeans know perfectly well what Mikuni Souichiro is saying. To quote "Bifo" Berardi:

The burden of debt is haunting the European imagination of the future, and the Union, which used to represent a promise of prosperity and peace, is turning into blackmail and a threat. (Berardi 2012: 57) The German banks have stored Greek time, Portuguese time, Italian time, and Irish time, and now the German banks are asking for their money back. They have stored the futures of the Greeks, the Portuguese, the Italians, and so on. Debt is actually future time - a promise about the future. (Berardi 2012: 84)

Mikuni Souichiro pumps the black money - the debt of future into his country's economy, but that debt, that finance is nothing but the future of Japanese people he gained by taking it from others, the debt stored in the Midas Bank. Berardi shows us the grim reality of European debt-oriented hyperreality, which is - I believe - built on the same principle [C] The Money of Soul represents and deconstructs.

Berardi in his critique of neoliberalism mentions banks. Let us look at the bank presented in [C] The Money of Soul, the Midas Bank. Its function as a monopolist is to issue and hold black money. The issuing is a very interesting mechanism, as only a few chosen people (those who received special darkness credit cards) can activate the printing press which uses their country's future as additional collateral: in the $9^{\text {th }}$ episode of the series Mikuni Souichiro uses the printing press and sees all the futures that will be sacrificed to save the present. Masakaki comments on his actions in the background: "So you have seen them. The futures that disappear as the Midas Money is printed.“ (Nakamura 2011: ep 9). And after Mikuni has finished printing the money to pump into Japan's failing economy Masakaki voices his mind again with a grim smile on his face: "Congratulations... You have protected... the present" (Nakamura 2011: ep 9). Thus the Midas Bank functions as an allegory of the neoliberal economy in times of crisis: to save the present one prints money to sacrifice the future. This is the true logic of debt-topia and debt economies - sustaining the present with a promise of future payment, collateral.

To fully understand this function of the Midas Bank and the place it occupies in the debt-topia of the Financial District it is crucial to reading the myth underlying the symbolic meaning of its naming. First of all, King Midas is known for two things, as Robert Graves and Kathleen Daly show us (Conf. Graves 1960; Daly 2004: 85-86): the ass's ears and the golden touch. In [C] The Money of Soul the head of Midas with the huge ears can be seen in a few scenes as a decoration on Masakaki's cane. These were given to Midas as punishment for not declaring Apollo the winner in a music contest with Pan. They seem to serve a minor role in the anime and function mainly as an explicit sign that Midas is somehow a father-figure of the Financial District. The second myth seems have more relevance to the functioning of the district and its main controlling entity. Midas receives the gift of the golden touch as a reward for taking care for Silenus, a follower of Dionysus. The myth states that Midas was later saved from this unfortunate fate by his beloved god, who told him to wash himself in the river Pactolus. Two things seem to be important when reading the story of [C] The 
Money of Soul utilizing the mythical symbolic: the nature of the golden touch, which points to the fact that the Midas Bank takes entrepreneurs' futures and turns them into black money, and that Midas's favorite deity is Dionysus, who is associated with wine, religious ecstasy, fertility and madness. The horror King Midas experiences when granted the gift of the golden touch is absolutely crucial to the understanding of the mechanism of the Midas Bank in the anime. What does it mean to turn everything into gold? It means to petrify reality, to turn it into one substance. Midas cannot eat or drink, and in a certain way he is also denied any contact with the surrounding world. The world of Midas may be golden and rich, but it has lost its future in this process of petrification into the substance of value - gold. This myth in [C] The Money of Soul depicts the state that neoliberalism has come to: it has petrified the world, turned it into a substance of The Same. And this is a paradox, as neoliberalism constantly uses the argument of mobility: innovation, the constant search for jobs, and moving masses of capital to hide this petrification.

But the myth of the golden touch is also tightly linked with one of the very first utopian visions, presented to King Midas by Silenus. Graves writes:

The gardeners bound him with garlands of flowers and led him before Midas, to whom he told wonderful tales of an immense continent lying beyond the Ocean stream - altogether separate from the conjoined mass of Europe, Asia, or Africa - where splendid cities abound, peopled by gigantic, happy, and long-lived inhabitants, and enjoying a remarkable legal system. A great expedition - at least ten million strong - once set out thence across the Ocean in ships to visit the Hyperboreans; but on learning that theirs was the best land that the old world had to offer, retired in disgust. (Graves 1960: 167)

According to Graves this story relates to the mythical island of Atlantis, but even if it was not true, as there are no hints to the name of the land mentioned by Silenus, the myth gives us a clear outline of an utopian continent. This story also serves as a comparison between the people from the distant utopian land and the current state of the world inhabited by Hyperboreans - and Midas's kingdom is a part of this disgusting world! Paradoxically, in describing the utopian society, Silenus evaluates Midas's domain, and I believe this should be the key factor in reading the meaning of the wish for the golden touch. With the utopian vision in mind, Midas is asking Dionysus for the power to change the worth of his world, and the god gives him exactly what he wished for (it is not a misinterpretation on his side as one might think). Midas is in fact mistaken as to the nature of utopia described by Silenus and the myth perfectly deconstructs his actions, namely: he mistakes utopian happiness for the pure desire for gold as the general equivalent and substance of value. To fully understand the implications of the golden touch and the problem of utopia it is crucial to analyze the meaning of touch and touching in this context. In The Sense of the World Jean-Luc Nancy writes about Heidegger's example of a stone, criticizing his reservation of touch to living beings:

The stone, no doubt, does not "handle" things (betasten), as Heidegger writes in what is, in the final analysis, a rather vulgar manner, evoking the indiscreet, exploratory connotation of a "fingering". But it does touch - or it touches on - with a passive transitivity. It is touched - same difference. The brute entelechy of sense: it is in contact, an absolute difference and an absolute différance. There is difference of places - that is to say, place - dis-location, without appropriation of one place 
by another. There is no "subject" and "object", but, rather, there are sites and places, distances: a possible world that is already a world. (Nancy 1997: 61)

Nancy says that to take away the touch from the stone would be to also take away its tactility, and Heidegger's gesture is deconstructed here as violent appropriation of the stone's place in the world by sense, its displacement into an abstract space - desensualization. That is why he ends his text saying:

In a sense - but what sense - the sense is touching. The being-here, side by side, of all these beingsthere (beings-thrown, beings-sent, beings abandoned to the there). (Nancy 1997: 63)

Nancy's idea of being with the world and not merely in the world sheds some light on the problem of King Midas's wish: "Pray grant that all I touch be turned into gold" (Graves 1960: 167). This wish is in fact an absolute negation of the world as the touching - sense - is converted to an economic recombination into gold. The very phrase "everything I touch" is already the ultimate act of violence against the world, against all that is being-there. What happens to Midas is the grim consequence of economic desensualization - you may convert, appropriate the world, but at the same you resign from sense - as the kernel of difference and différance. In a sense Midas is touching himself out of the world... And if we look at the characters in [C] The Money of Soul they are put in a very similar position, as everything they construct with Midas black money is in a way out of the world and functions according to the logic of hyperreality. But that is not all: the golden touch signifies the absolute resignation from this specific mode of being which is touching, existing with the world where singular events are possible. Within the golden world transformed by the golden touch the eventfulness ceases to exist, what is left is a golden desert of the substance of value without reference. There is no room for passive transitivity when the golden touch is involved - the beings-there are lost to the being-here that touches them, as the touch no longer differentiates, no longer discovers different senses, it now brings the totality of the sense of gold. And this myth, and the parable we may read in it is the universal parable of neoliberalism, which - paradoxically - appropriated the Midas touch (Conf. Trump and Kiyosaki 2011) to name the methods of earning money...

In the anime the only functioning sign of the Midas Bank is a huge coin-shaped calculator in the center of each Financial District. This of course refers to the famous USA National Debt Clock installed on Sixth Avenue in Manhattan. The objective of the New York clock is to show the steady growth of the national debt (or the promise of the future as Berardi would say), while the debt clock in [C] The Money of Soul counts the total sum of assets present in each end every city. But the assets are a representation of one's future, meaning exactly that what is being calculated and counted is the collective future of all who utilize the black money. The only difference is that the USA clock counts upwards, while the clock in the anime counts downwards, which seems to be a very interesting move. While we tend to think of the debt as a promise of future payment, the representation of the growing debt seems to mislead us into believing that it is an actual growth - this is a true paradox. The Financial District's debt clock counts not the amount of future as a surplus of debt, but the amount of future as a deficit of possibilities. What happens when the counter hits zero? In [C] The Money of Soul the city of Shanghai as the East Asian Financial District's heart 
disappears from reality along with the virtual district... Debt-topia claims reality with its fall. This simple turning of the vision of debt upside down is a perfect deconstruction of the real problem we are facing - that the growth of debt is perceived as growth when it should have been the opposite. The debt itself is being presented in neoliberal rhetoric, as if it was an index of some kind of stock good, but this rhetoric only masks the true meaning of the debt clock - that it counts against the alternatives for the future.

\section{REFERENCES}

Baudrillard, Jean. 1983. Simulacra and Simulations, trans. by Paul Foss, Paul Patton, Philip Beitchman, New York: Semiotext(e).

Beradi, Franco "Bifo". 2012. The Uprising On Poetry and Finance, London: Semiotext(e). Bourdieu, Pierre. 1998. Utopia of endless exploitation. The essence of neoliberalism, trans. by Jeremy J. Shapiro, https://mondediplo.com/1998/12/08bourdieu [01.03.2016].

[C] The Money of Soul. Wiki: http://soulcontrol.wikia.com/wiki/Masakaki [01.03.2016].

Chung, John J. 2009. Money as Simulacrum: The legal nature and reality of money, "Hastings Business Law Journal" 5: 109-167.

Daly, Kathleen N. 2004. Greek and Roman Mythology A to Z, New York: Facts On File.

Dean, Jodi and Mark Fisher. 2014. We Can't Afford to Be Realists: A Conversation in Alison Shonkwiler and Leigh Claire La Berge (eds), Reading Capitalist Realism, Iowa City: University of Iowa Press.

Goethe, Johann Wolfgang von. 2014. Faust I\&2 Goethe's Collected Works, Vol. 2, trans. by Stuart Atkins, New Jersey: Princeton University Press.

Graves, Robert. 1960. The Greek Myths Complete Edition, London: Penguin.

Hodgson, Geoffrey M.1999. Economics and Utopia. Why the learning economy is not the end of history, London: Routledge.

Hörisch, Johen. 2000. Heads and Tails: The Poetics of Money, trans. by Amy Horning Marschall, Detroit: Wayne State University Press.

Jameson, Fredric. 2005. Archaeologies of The Future The Desire Called Utopia and Other Science Fictions, London: Verso.

Lazzarato, Maurizio. 2012. The making of an indebted man: An essay on the neoliberal condition, trans. by Joshua David Jordan, Amsterdam: Semiotext(e).

McManus, Susan. 2003. Fabricating the Future: Becoming Bloch's Utopians, "Utopian Studies" 14, 2: 1-22.

Nakamura, Kenji (ed.). 2011. [C] The Money of Soul and Possibility Control, Tatsunoko Production Japan.

Nancy, Jean-Luc. 1997. The Sense of the World, trans. by Jeffrey S. Librett, London: University of Minnesota Press.

Sargent, Layman Tower. 1994. The Three Faces of Utopianism Revisited, "Utopian Studies" 5, 1: 1-37.

Smith, Richard G. (ed.). 2010. The Baudrillard Dictionary, Edinburgh: Edinburgh University Press. 
Trump, Donald J. and Robert T. Kiyosaki. 2011. Midas Touch, why some entrepreneurs get rich and why most don't, Plata Publishing, LLC.

Žižek, Slavoj. 2009. First as Tragedy, Then as Farce, London: Verso.

\section{CZARNY PIENIA¿DZ JAKO MATERIA NEOLIBERALNEJ UTOPII - CZYTAJĄC [C] THE MONEY OF SOUL AND POSSIBILITY CONTROL}

Tekst Czarny pieniqdz jako materia neoliberalnej utopii - czytajac [C] The Money of Soul and Possibility Control poświęcony jest problematyce neoliberalnej utopii długu. Autor analizuje w nim anime japońskiego reżysera Kenji Nakamury pod kątem występujących w nim motywów i reprezentacji związanych z problematyką ekonomii: czarny pieniądz, dług, bank Midasa. Tekst skupia się na relacji pomiędzy czarnym pieniądzem a produkowaniem hiperrzeczywistości oraz na problemie długu, konkurencji i zepsucia ogólnego ekwiwalentu jako głównych filarach zarówno przedstawienia, jak i krytyki neoliberalnej utopii. Autor w swojej interpretacji odwołuje się do badaczy utopii (Fredric Jameson, Lyman Tower Sargen, Geoffrey Hodgson) oraz do współczesnych krytyków neolibealizmu (Franco „Bifo” Berardi, Maurizzio Lazzarato, Pierre Bourdieu, Slavoj Žižek).

Słowa kluczowe: czarny pieniądz, neoliberalizm, utopia, dług, anime, Nakamura 